\title{
Role of Anopheles (Cellia) rufipes (Gough, 1910) and other local anophelines in human malaria transmission in the northern savannah of Cameroon: a cross- sectional survey
}

Raymond N. Tabue ${ }^{1,2,3+}$, Parfait Awono-Ambene ${ }^{4 \dagger}$, Josiane Etang ${ }^{4 \dagger}$, Jean Atangana ${ }^{3 \dagger}$, Antonio-Nkondjio $C^{4 \dagger}$, Jean C. Toto ${ }^{4 \dagger}$, Salomon Patchoke ${ }^{3 \dagger}$, Rose G.F. Leke ${ }^{2 \dagger}$, Etienne Fondjo ${ }^{3+}$, Abraham P. Mnzava ${ }^{5+}$, Tessa B. Knox ${ }^{5+}$, Alexis Tougordi ${ }^{6 \dagger}$, Martin J. Donnelly ${ }^{7,8+}$ and Jude D. Bigoga ${ }^{1,2^{*}}$

\begin{abstract}
Background: As part of a study to determine the impact of insecticide resistance on the effectiveness of longlasting insecticide treated nets (LLINS) in the north of Cameroon, the unexpectedly high density and anthropophilic behaviour of Anopheles rufipes lead us to investigate this species bionomics and role in human malaria parasite transmission.

Methods: For four consecutive years (2011-2014), annual cross-sectional sampling of adult mosquitoes was conducted during the peak malaria season (September-October) in three health districts in northern Cameroon. Mosquitoes sampled by human landing catch and pyrethrum spray catch methods were morphologically identified, their ovaries dissected for parity determination and Anopheles gambiae siblings were identified by molecular assay. Infection with $P$. falciparum and blood meal source in residual fauna of indoor resting anopheline mosquitoes were determined by enzyme-linked-immunosorbent assays.
\end{abstract}

Results: Anopheles gambiae (sensu lato) (s.l.) comprised 18.4\% of mosquitoes collected with An. arabiensis representing $66.27 \%$ of the sibling species. The proportion of An. rufipes (2.7\%) collected was high with a humanbiting rate ranging between 0.441 and 11.083 bites/person/night $(\mathrm{b} / \mathrm{p} / \mathrm{n})$ and an anthropophagic rate of 15.36\%. Although overall the members of An. gambiae complex were responsible for most of the transmission with entomological inoculation rates (EIR) reaching 1.221 infective bites/person/night (ib/p/n), An. arabiensis and $A n$. coluzzii were the most implicated. The roles of An. funestus, An. pharoensis and An. paludis were minor. Plasmodium falciparum circumsporozoite protein rate in Anopheles rufipes varied from 0.6 to $5.7 \%$ with EIR values between 0.010 and $0.481 \mathrm{ib} / \mathrm{p} / \mathrm{n}$.

(Continued on next page)

\footnotetext{
* Correspondence: jbigoga@gmail.com

${ }^{\dagger}$ Equal contributors

${ }^{1}$ Faculty of Science, Department of Biochemistry, University of Yaounde I,

P.O. Box 813- Messa, Yaounde, Cameroon

${ }^{2}$ National Reference Unit for Vector Control, The Biotechnology Center,

University of Yaoundé I, P.O. Box 3851-Messa, Yaoundé, Cameroon

Full list of author information is available at the end of the article
} 
(Continued from previous page)

Conclusions: The study highlights the epidemiological role of An. rufipes alongside the members of the An. gambiae complex, and several other sympatric species in human malaria transmission during the wet season in northern Cameroon. For the first time in Cameroon, An. rufipes has been shown to be an important local malaria vector, emphasising the need to review the malaria entomological profile across the country as pre-requisite to effective vector management strategies.

Keywords: Malaria, Transmission, Anopheles, Local vectors, Northern Cameroon

\section{Background}

The discovery at the turn of the nineteenth century that malaria was transmitted by mosquitoes initiated an outburst of interest in the description and implication of various species in malaria transmission [1]. Human plasmodial species are transmitted by mosquitoes of the genus Anopheles, which includes 465 formally recognised species [2]. Amongst these, over 140 species have been identified in Africa [3, 4], of which less than 20 have been shown to support the development and propagation of human Plasmodium species [5]. However, their relative contribution to malaria transmission greatly varies depending on their behaviour (host seeking, feeding and resting) and densities as influenced by environmental conditions. These differences in Anopheles behaviour and density, along with vector longevity, are key factors driving malaria transmission and epidemiological patterns observed across Africa $[6,7]$. Therefore, in areas with numerous potential vectors, an in-depth understanding of vectors dynamics is fundamental to designing interventions tailored to the local eco-epidemiological situation $[8,9]$.

The malaria vectorial system in Cameroon is very complex. To date, over 50 Anopheles species have been described which are heterogeneously distributed across the eco-epidemiological zones of the country. Fifteen species have been demonstrated to support the development and spread of human Plasmodium spp.: An. gambiae Giles, 1902; An. funestus Giles, 1900; An. arabiensis Patton, 1905; An. nili (Theobald, 1904) and An. moucheti Evans, 1925 are classified as major vectors [10]. The other species amongst which are An. pharoensis and An. paludis play only a minor localised secondary role in transmission [1114], and they may help to augment or extend the malaria transmission period $[15,16]$. For the first time we report the importance of An. rufipes (Gough, 1910), as vector of human Plasmodium in Cameroon. Although a few studies have attempted to associate An. rufipes with human malaria transmission $[17,18]$, this species has generally been reported to be zoophilic $[3,4]$ with high densities in ricegrowing areas $[19,20]$. Even though this species has often been collected landing on human volunteers in several studies in Cameroon [21-23], its role in malaria transmission has never been investigated.

\section{Methods \\ Study site and design}

For four consecutive years (2011-2014), annual crosssectional sampling of adult Anopheles mosquitoes was conducted in Northern Cameroon during the peak malaria season (September-October) in the health districts (HD) of Pitoa $\left(9^{\circ} 23^{\prime} 0^{\prime \prime N}, 13^{\circ} 32^{\prime} 0 " \mathrm{E}\right)$, Garoua $\left(9^{\circ} 18^{\prime} 0^{\prime \prime} \mathrm{N}, 13^{\circ}\right.$ 24' 0" E) and Oulo Mayo (9 $7^{\circ} 34^{\prime \prime N}, 13^{\circ} 37^{\prime} 20^{\prime \prime E}$ ) (Fig. 1). A total of 38 villages (12, 17 and 9 villages from each HD, respectively) were included in the assessment. Pitoa is a peri-urban area with about 108,611 inhabitants. The main economic activity is farming with major crops cultivated being rice, cotton, millet, sorghum and maize. On the other hand, Garoua is an urban area with a population of around 316,957 with rural suburbs that depend almost entirely on agriculture for subsistence. Mayo Oulo is predominantly rural, highland area with around 91,501 inhabitants. Unlike in the suburbs of Garoua where typically corn, tomatoes and eggplant are grown, in Mayo Oulo major crops cultivated are maize, beans and peanuts. All three areas have a Sahelian-type climate with an annual average rainfall of $700-1,000 \mathrm{~mm}$ and annual average temperature of $26-33{ }^{\circ} \mathrm{C}$. Anopheles gambiae (s.l.) is the major malaria vector along with typical sahelian vectors including An. funestus and An. pharoensis, and Plasmodium falciparum is the most prevalent malaria parasite species $[24,25]$.

\section{Field sampling of adult mosquitoes}

Mosquitoes were sampled using both the human landing catch (HLC) and pyrethrum spray collection (PSC) methods. Mosquito collections took place concurrently in all 38 villages within the three HDs. HLCs were performed for two consecutive nights from 18:00-06:00 h. Mosquitoes were collected indoors and outdoors in three randomly selected houses (at least $50 \mathrm{~m}$ apart) in each village each night with rotation between houses at different locations. A team of four trained volunteers per house (two working during the first half of the night and the others during the second half of the night) made the collection, with one sitting inside the house and the other on the veranda collected female mosquitoes as they landed on exposed lower limbs. The mosquitoes were sorted by genus and the anophelines identified 


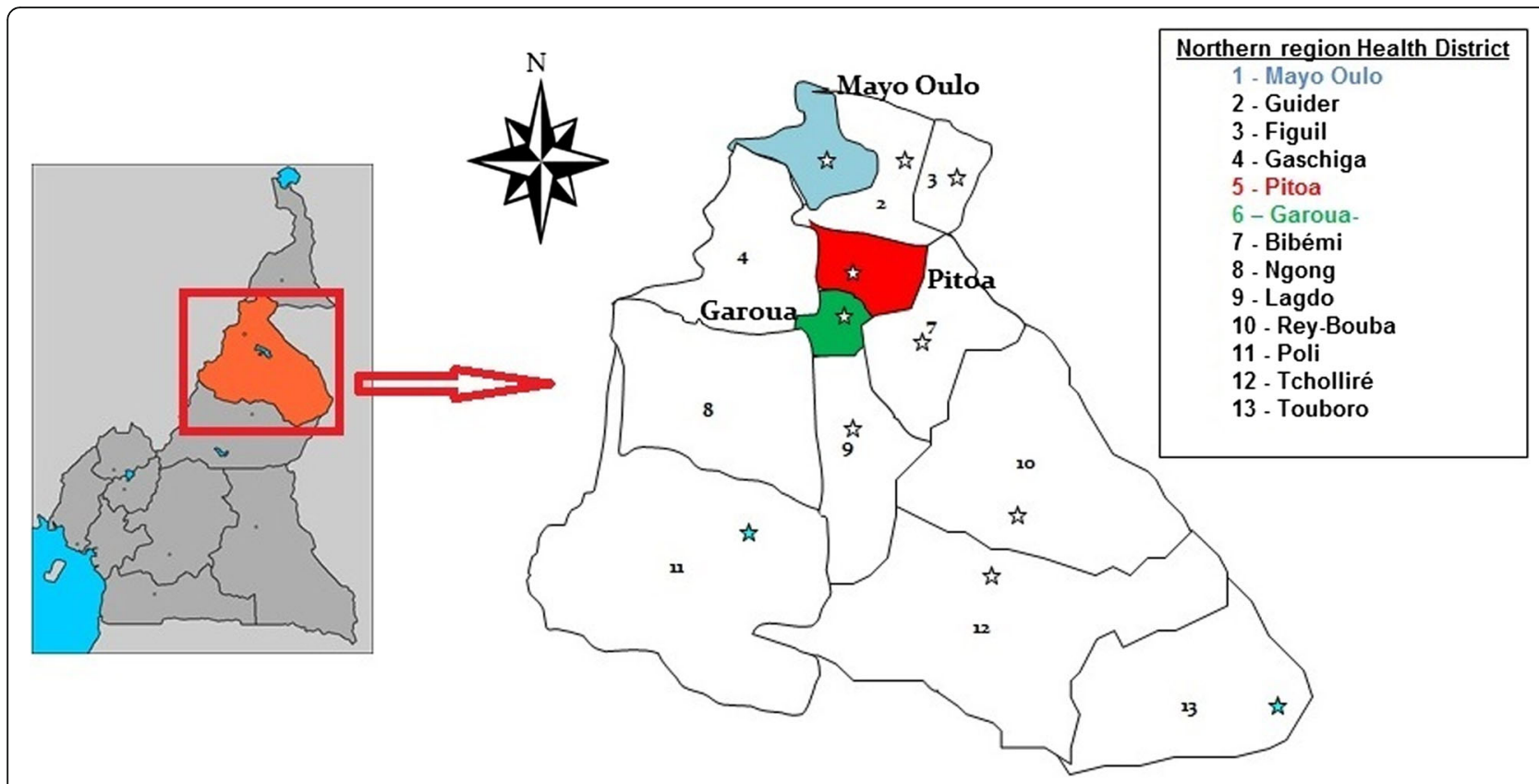

Fig. 1 Map of the North region of Cameroon showing the study Health Districts (1, 5 and 6)

morphologically using the morphological identification keys of Gillies \& de Meillon [3] and Gillies \& Coetzee [4]. The ovaries of a proportion of unfed mosquitoes were dissected for parity determination [26]. All dissected and those undissected mosquitoes were individually stored in tubes containing silica gel for subsequent laboratory analyses. PSCs for indoor resting mosquitoes were performed once in the morning (06:00-08:00 h) as described by Service et al. [27], and the mosquitoes were identified morphologically with their physiological status recorded. Specimens were individually stored desiccated in tubes for later laboratory analyses.

\section{Laboratory analysis of Anopheles spp. mosquitoes}

A portion of specimens from each collection method belonging to the Anopheles gambiae complex were further identified using molecular assays. DNA from the legs and wings of each individual specimen was extracted [28] and PCR amplification was conducted to determine species [29]. The head and thorax portion of each Anopheles female collected was separated from the rest of the body, homogenized in grinding buffer $(0.5 \%$ Casein, $0.1 \mathrm{~N} \mathrm{NaOH}, 1 \times \mathrm{PBS}$ ) and examined for the presence of Plasmodium falciparum circumsporozoite protein (CSP) by enzyme-linked-immunosorbent assay (ELISA) [30, 31]. This was to avoid cross reactivity with animal blood as reported previously [32]. To minimize false positive CSP ELISA, only high absorbance readings were considered (mean plus three standard deviations of negative controls). Blood-fed females resting indoors were screened for the source of blood meal by ELISA as described by Beier et al. [33] and modified by Lardeux et al. [34]. Monoclonal antibodies against human, cow, pig and sheep blood were used.

\section{Data analysis}

Man biting rate (ma) was calculated as the average number of bites from Anopheles species received per person per night of collection. Infection Rate (IR) was calculated as the proportion of Anopheles species tested positive for P. falciparum CSP by ELISA, while the Human Blood Index (HBI) represented the proportion of Anopheles species identified by ELISA to have fed on human blood. The Entomological Inoculation Rate (EIR) was determined as the product of the Infection Rate (IR) and the man biting rate (ma). Data were analysed using SPSS Statistics 17.0. A Chi-square test was used to determine variable significance and the threshold for statistical significance was set at $P<0.05$.

\section{Results}

\section{Mosquito composition and anopheline density}

A total of 80,689 mosquitoes were collected by HLC, comprising 61.7\% Culex spp., 26.7\% Anopheles spp., 11.1\% Mansonia spp., 0.3\% Aedes spp. and 0.2\% Coquillettidia spp. Overall 21,571 Anopheles mosquitoes were identified morphologically (Table 1), of which there were 14,858 An. gambiae (s.l.), 2,169 An. rufipes, 1,802 An. pharoensis, 1,259 An. funestus and 659 An. paludis. The remaining $1 \%$ (824) of anopheline species were scarce and their occurrence varied greatly between the villages and health districts (Table 1). 
Table 1 Composition and abundance of mosquitoes by species and study health district

\begin{tabular}{lllll}
\hline Species & $\begin{array}{l}\text { Garoua } \\
\%(n)\end{array}$ & $\begin{array}{l}\text { Pitoa } \\
\%(n)\end{array}$ & $\begin{array}{l}\text { Mayo Oulo } \\
\%(n)\end{array}$ & $\begin{array}{l}\text { Total } \\
\%(n)\end{array}$ \\
\hline Anopheles spp. & & & & \\
An. gambiae (s.l.) & $14.7(5,138)$ & $22.7(7,774)$ & $17.0(1,946)$ & $18.4(14,858)$ \\
An. rufipes & $0.7(234)$ & $2.1(722)$ & $10.6(1,213)$ & $2.7(2,169)$ \\
An. pharoensis & $2.8(965)$ & $2.0(699)$ & $1.2(138)$ & $2.2(1,802)$ \\
An. funestus & $1.4(496)$ & $1.7(591)$ & $1.5(172)$ & $1.6(1,259)$ \\
An. paludis & $0.8(270)$ & $1.0(357)$ & $0.3(32)$ & $0.8(659)$ \\
Other Anopheles spp. & $0.1(29)$ & $1.4(479)$ & $2.8(316)$ & $1.0(824)$ \\
Total 1 & $20.4(7,132)$ & $31.0(10,622)$ & $33.4(3,817)$ & $26.7(21,571)$ \\
Culicines & & & & \\
Culex spp. & $74.5(26,111)$ & $50.0(17,111)$ & $57.3(6,554)$ & $61.7(49,776)$ \\
Mansonia spp. & $4.6(1,618)$ & $18.8(6,434)$ & $7.8(886)$ & $11.1(8,938)$ \\
Aedes spp. & $0.1(20)$ & $0.1(49)$ & $1.5(171)$ & $0.3(240)$ \\
Coquillettidia spp. & $0.4(156)$ & $0.0(7)$ & $0.0(1)$ & $0.2(164)$ \\
Total 2 & $79.6(27,905)$ & $69.0(23,601)$ & $66.6(7,612)$ & $73.3(59,118)$ \\
Total 1+2 & $100(35,037)$ & $100(34,223)$ & $100(11,429)$ & $100(80,689)$ \\
\hline Abrevaton & & & &
\end{tabular}

Abbreviation: $n$ number collected

\section{Molecular identification of Anopheles gambiae siblings}

A total of 1,002 An. gambiae (s.l.) collected by HLC between 2011 and 2014 were identified by molecular methods. There were 664 (66.27\%) An. arabiensis, 258 (25.75\%) An. coluzzii and 80 (7.98\%) An. gambiae (s.s.). Stratifying by health district, there were a total of 314 Anopheles gambiae (s.l.) tested in Mayo Oulo amongst which there were $83.12,8.28$ and $8.60 \%$ of $A n$. arabiensis, An. coluzzii and
An. gambiae (s.s.), respectively. In Garoua, 426 were analysed comprising 55.28, 38.30, and 6.42\% of An. arabiensis, An. coluzzii and An. gambiae (s.s.), respectively. Meanwhile in Pitoa, out of 252 An. gambiae (s.l.) identified, there were 64.29\% An. arabiensis, 25.79\% An. coluzzii and 9.92\% An. gambiae (s.s.). Thus, Anopheles arabiensis was the most abundant of the An. gambiae (s.l.) siblings collected by HLC in all three health districts, followed by An. coluzzii (Fig. 2). Based on analyses of anophelines collected by PSC, a total of 888 anopheles species comprising 472 (53.15\%) An. gambiae (s.l.), 364 (40.99\%) An. funestus and 52 (5.86\%) $A n$. rufipes were collected. Amongst the members of the An. gambiae (s.l.), An. arabiensis (77.97\%) was the most abundant, followed by $A n$. coluzzii (16.95\%) and An. gambiae (5.08\%).

\section{Night biting rate and biting cycles}

The human-biting rates varied by species and health district. While peak biting rates for An. gambiae (s.l.) were recorded in Garoua and Pitoa health districts, in Mayo Oulo An. rufipes had the highest biting rates in 2012 and 2013 at $11.083 \mathrm{~b} / \mathrm{p} / \mathrm{n}$ and $7.852 \mathrm{~b} / \mathrm{p} / \mathrm{n}$ respectively (Table 2). The human-biting rate of $A n$. funestus, $A n$. pharoensis and An. paludis were higher in Pitoa HD compared to Garoua and Mayo Oulo HD. There was no preference to the place of bite for the main Anopheles species as they could bite indoor as well as outdoor (Fig. 3).

Comparative analysis of the biting trends by hour of the night between $A n$. rufipes and the major vector $A n$. gambiae (s.l.) showed great variation in the peak aggressivitiy between the health districts (Fig. 4). While

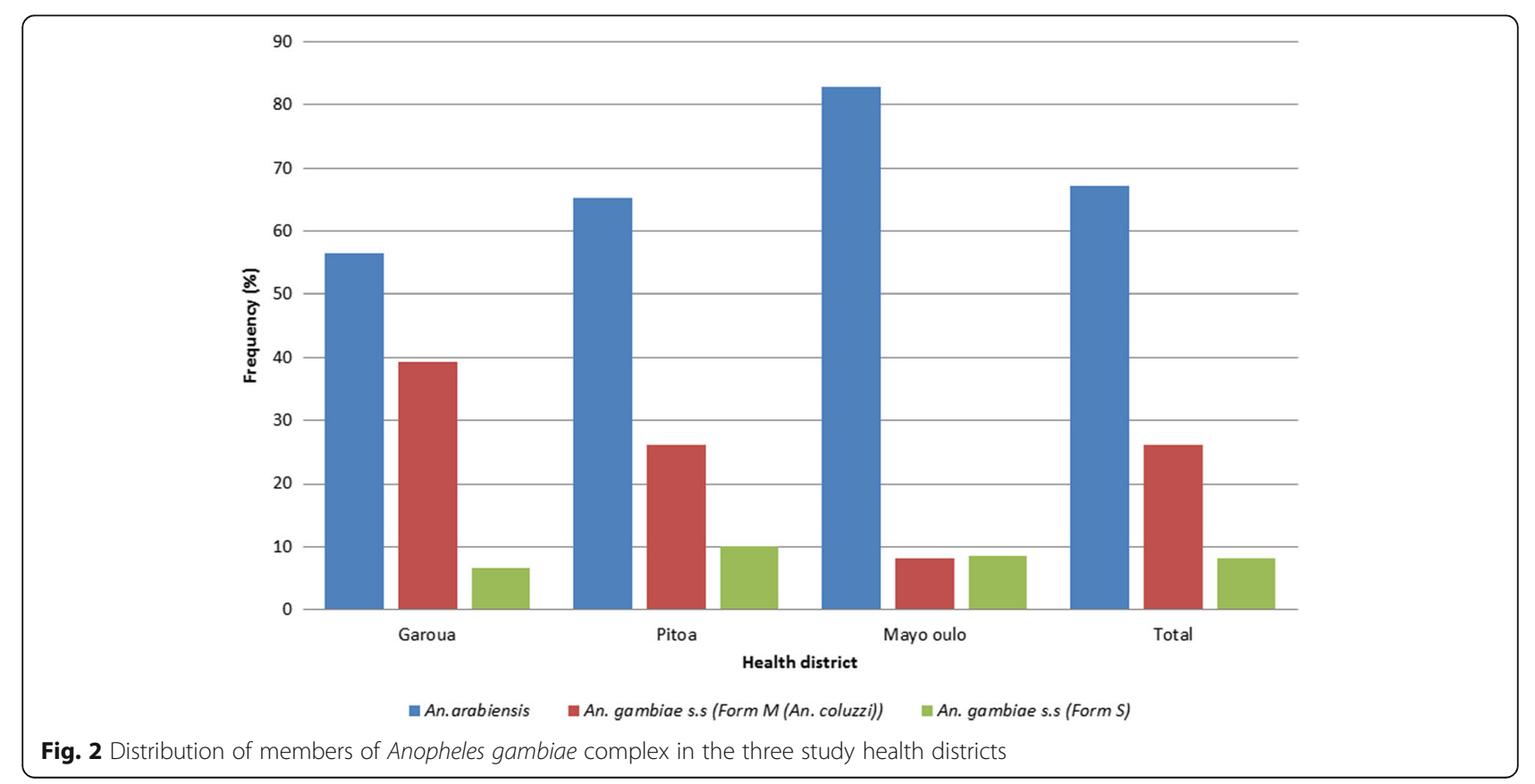


Table 2 Average man biting rate (number of bites per person per night) for Anopheles species in the study sites from 2011 to 2014

\begin{tabular}{|c|c|c|c|c|c|c|c|c|c|c|c|c|}
\hline \multirow{2}{*}{$\begin{array}{l}\text { Anopheles species } \\
\text { or complex }\end{array}$} & \multicolumn{4}{|c|}{ Garoua } & \multicolumn{4}{|l|}{ Pitoa } & \multicolumn{4}{|c|}{ Mayo Oulo } \\
\hline & 2011 & 2012 & 2013 & 2014 & 2011 & 2012 & 2013 & 2014 & 2011 & 2012 & 2013 & 2014 \\
\hline An. gambiae (s.l.) & 20.14 & 8.90 & 17.12 & 4.21 & 39.74 & 24.26 & 22.11 & 21.88 & 39.36 & 3.47 & 6.24 & 11.16 \\
\hline An. funestus & 1.14 & 0.77 & 1.92 & 1.02 & 4.47 & 2.01 & 0.94 & 0.90 & 1.89 & 1.28 & 1.04 & 1.00 \\
\hline An. pharoensis & 6.23 & 0.12 & 2.72 & 0.83 & 4.22 & 0.65 & 2.88 & 2.05 & 2.06 & 0.08 & 1.06 & 0.67 \\
\hline An. paludis & 0.03 & 1.19 & 1.12 & 0.32 & 1.81 & 1.94 & 1.28 & 0.04 & 0.03 & 0.11 & 0.48 & 0.33 \\
\hline An. rufipes & 0.66 & 0.66 & 0.44 & 0.54 & 5.49 & 3.57 & 0.47 & 0.51 & 8.42 & 11.08 & 7.85 & 10.83 \\
\hline
\end{tabular}

Anopheles gambiae (s.l.) was as most aggressive between 24:00 and 2:00 h in Pitoa and Garoua, in Mayo Oulo its peak activity was earlier, between 22:00 and 24:00 h. On the other hand, An. rufipes was most aggressive between 20:00 and 24:00 h in Garoua, 22:00 and 24:00 h in Pitoa, and in the mountainous Mayo Oulo, it was most active between 24:00 and 06:00 h (Fig. 4).

\section{Parity rates}

Out of a total of 10,225 ovaries of Anopheles species dissected, 4,438 were parous, giving an overall parity rate of $43.40 \%$. The parity rate was higher for An. gambiae (s.l.), 46.92\% (45.77-48.08), compared to An. funestus, An. rufipes, $A n$. pharoensis and An. paludis with parity rates of $37.92,36.94,31.12$ and $27.67 \%$, respectively (Table 3). With regard to the health district, although generally the highest parity rates were observed in Pitoa, the difference in parity rate between HDs and anopheline species was not significant $\left(\chi^{2}=6.62, d f=8, P=0.58\right)$. However, there was a significant difference in An. gambiae (s.l.) parity rates between the health districts $\left(\chi^{2}=8.42, d f=2, P=\right.$ $0.0145)$, which could directly impact on their relative contribution to transmission in the HDs.

\section{Human blood index (HBI)}

In total, the blood meal source of 472 (53.15\%) out of the 888 blood-fed Anopheles species tested were confirmed. Of these, $21.62 \%$ were solely of human origin, $15.99 \%$ were from cow and $1.80 \%$ from pig. However, there were cases of mixed blood from varied sources such as cow and sheep (8.33\%), human and pig (2.48\%), and cow, pig and sheep (1.35\%). Amongst the members of An. gambiae complex, Anopheles gambiae was observed to feed essentially on human blood, while An. arabiensis and $A n$. coluzzii, alongside other species like $A n$. funestus and $A n$. rufipes fed both on humans and a wide range of domestic animals. About $47 \%$ of the source of blood meal from fed Anopheles species was not identified, probably due to the lack of monoclonal antibodies to test for blood meals from several other animal species commonly found in those

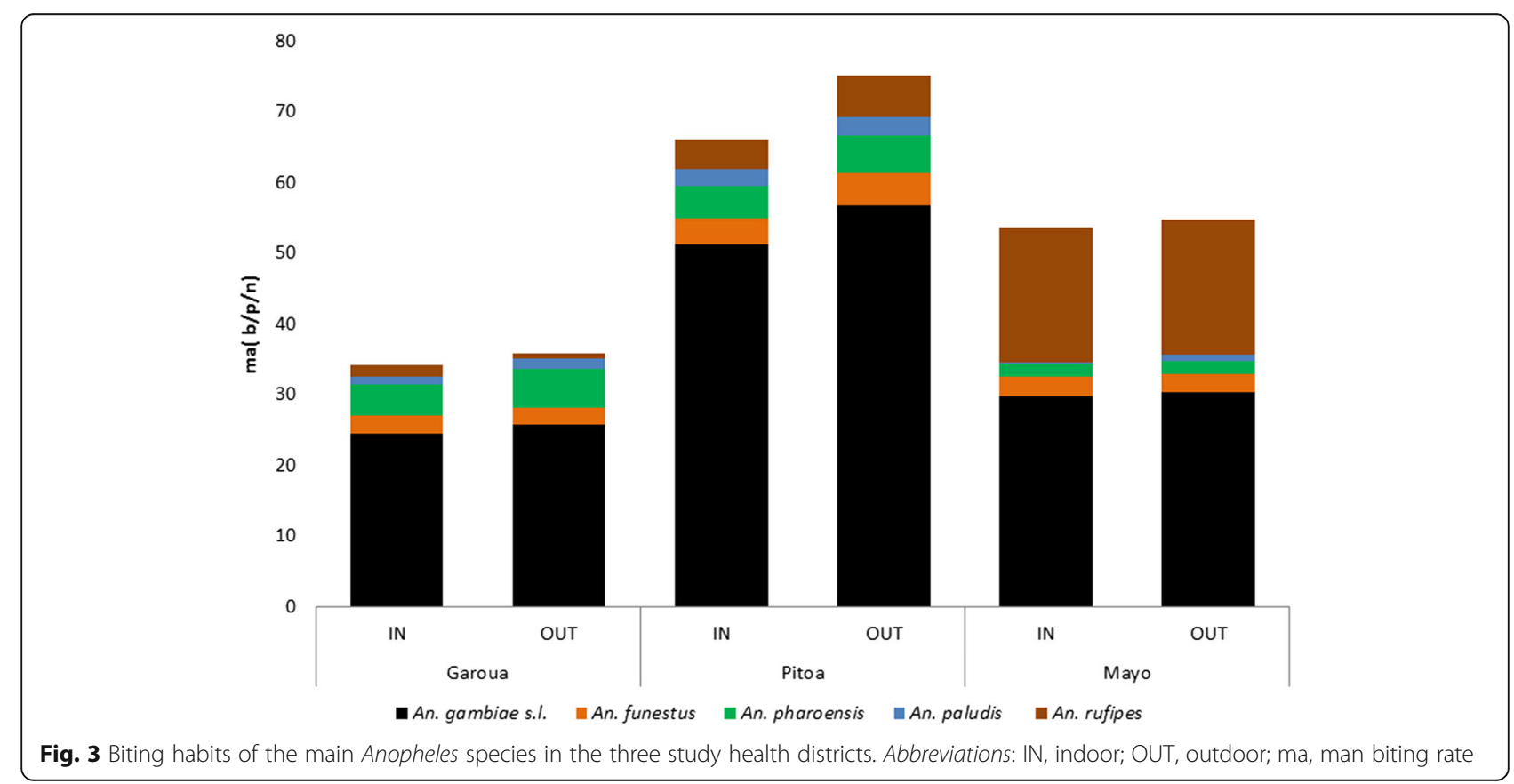




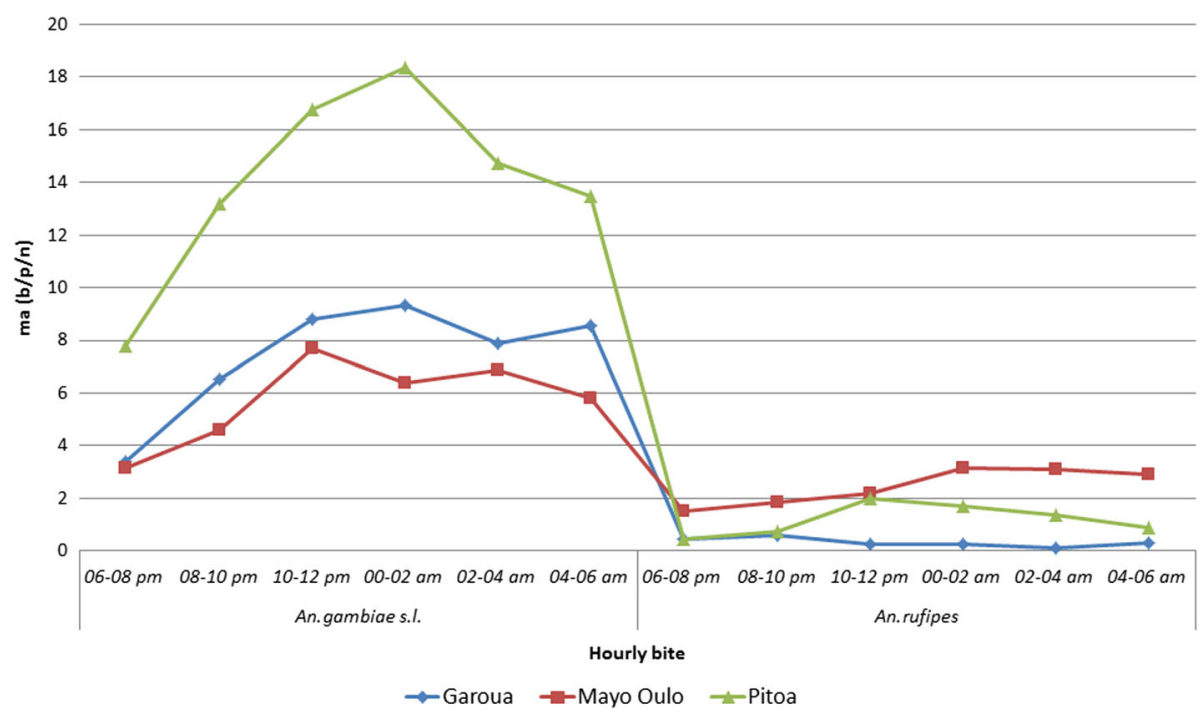

Fig. 4 Hourly biting activity of Anopheles vector species in three health districts. Abbreviation: ma, man biting rate

localities (horse, goat, donkey and dog) (Fig. 5). Generally, Anopheles gambiae was the most anthropohilic of the Anopheles species tested. Also, it had the highest human blood index (HBI) (66.67\%) amongst the members of the An. gambiae complex $\left(\chi^{2}=23.36, d f=2, P<0.05\right)$ followed by $A n$. coluzzii (31.25\%) and An. arabiensis (26.36\%). The HBI for An. rufipes was $15.38 \%$ while An. funestus had the least (12.64\%).

\section{Infectivity and entomological inoculation rate (EIR)}

Details of the EIR by vector species and health district are presented in Tables 4 and 5 . Overall, the CSP rates varied from 0.8 to $9.1 \%$ (Table 4). Irrespective of the year and health district, data indicated that An. gambiae (s.l.) was responsible for most of the Plasmodium transmission. In Mayo Oulo where the highest number of $A n$. rufipes was collected, this species accounted for EIR values ranging from 0.286 to 0.481 infective bites per person per night (ib/p/n) in 2012 and 2011, respectively. However, the highest EIR for An. gambiae (s.l.) (1.52 ib/p/n) was obtained in 2011 (Fig. 6). The highest EIR for $A n$. funestus and An. pharoensis were $0.032 \mathrm{ib} / \mathrm{p} / \mathrm{n}$ in 2012 and $0.044 \mathrm{ib} / \mathrm{p} / \mathrm{n} 2013$, respectively. In Pitoa health district, An. gambiae (s.l.) was also responsible for most of the transmission having EIR rates between $0.280 \mathrm{ib} / \mathrm{p} / \mathrm{n}$ in 2014 and $1.368 \mathrm{ib} / \mathrm{p} / \mathrm{n}$ in 2011. While the EIR for Anopheles rufipes ranged from 0.022 to $0.222 \mathrm{ib} / \mathrm{p} / \mathrm{n}$, peak values for An. funestus, An. pharoensis and An. paludis were $0.139 \mathrm{ib} / \mathrm{p} / \mathrm{n}, 0.200 \mathrm{ib} / \mathrm{p} / \mathrm{n}$ and $0.052 \mathrm{ib} / \mathrm{p} / \mathrm{n}$, respectively during the 4 years. The lowest EIR values were obtained in Garoua HD. Here, the EIR for An. gambiae (s.l.) varied between $0.079 \mathrm{ib} / \mathrm{p} / \mathrm{n}$ in 2014 and $0.340 \mathrm{ib} / \mathrm{p} / \mathrm{n}$ in 2011 . For An. pharoensis the highest EIR was $0.090 \mathrm{ib} / \mathrm{p} / \mathrm{n}$ in 2011.

With regards to the members of the Anopheles gambiae complex, although in general An. arabiensis recorded the highest EIR, with peak values of $0.029 \mathrm{ib} / \mathrm{p} / \mathrm{n}$ in 2013 in Garoua, $0.028 \mathrm{ib} / \mathrm{p} / \mathrm{n}$ in 2011 in Pitoa and $0.093 \mathrm{ib} / \mathrm{p} / \mathrm{n}$ in 2011 in Mayo Oulo, the difference was not significant when compared to An. colluzii in Garoua

Table 3 Parity rates of Anopheles vectors of malaria in the three study health districts

\begin{tabular}{lllllll}
\hline Health district & & An. gambiae (s.l.) & An. funestus & An. pharoensis & An. paludis & An. rufipes \\
\hline Garoua & No. dissected (No. parous) & $2,119(765)$ & $449(177)$ & $276(68)$ & $69(18)$ & $80(25)$ \\
& Parous rate (\%) (95\% Cl) & $36.10(34.08-38.17)$ & $39.42(35.01-44.01)$ & $24.64(19.93-30.05)$ & $26.09(17.19-37.51)$ & $31.25(22.15-42.07)$ \\
\multirow{2}{*}{ Pitoa } & No. dissected (No. parous) & $3,856(2,207)$ & $367(132)$ & $342(124)$ & $172(49)$ & $178(84)$ \\
& Parous rate (\%) (95\% Cl) & $57.24(55.67-58.79)$ & $35.97(31.23-41.00)$ & $36.26(31.34-41.48)$ & $28.49(22.27-35.65)$ & $47.19(39.99-54.51)$ \\
\multirow{2}{*}{ Mayo Oulo } & No. dissected (No. parous) & $1,184(387)$ & $136(52)$ & $60(19)$ & $12(3)$ & $925(328)$ \\
& Parous rate (\%) (95\% Cl) & $32.69(30.07-35.41)$ & $38.24(30.50-46.62)$ & $31.67(21.31-44.23)$ & $25.00(8.89-53.23)$ & $35.46(32.44-38.60)$ \\
\multirow{2}{*}{ Total } & No. dissected (No. parous) & $7,159(3,359)$ & $952(361)$ & $678(211)$ & $253(70)$ & $1,183(437)$ \\
& Parous rate (\%) (95\% Cl) & $46.92(45.77-48.08)$ & $37.92(34.89-41.04)$ & $31.12(27.75-34.70)$ & $27.67(22.52-33.48)$ & $36.94(34.24-39.73)$
\end{tabular}

Note: The difference in parity rate between health districts and anopheline species was not significant $\left(X^{2}=6.62, d f=8, P=0.58\right)$ 


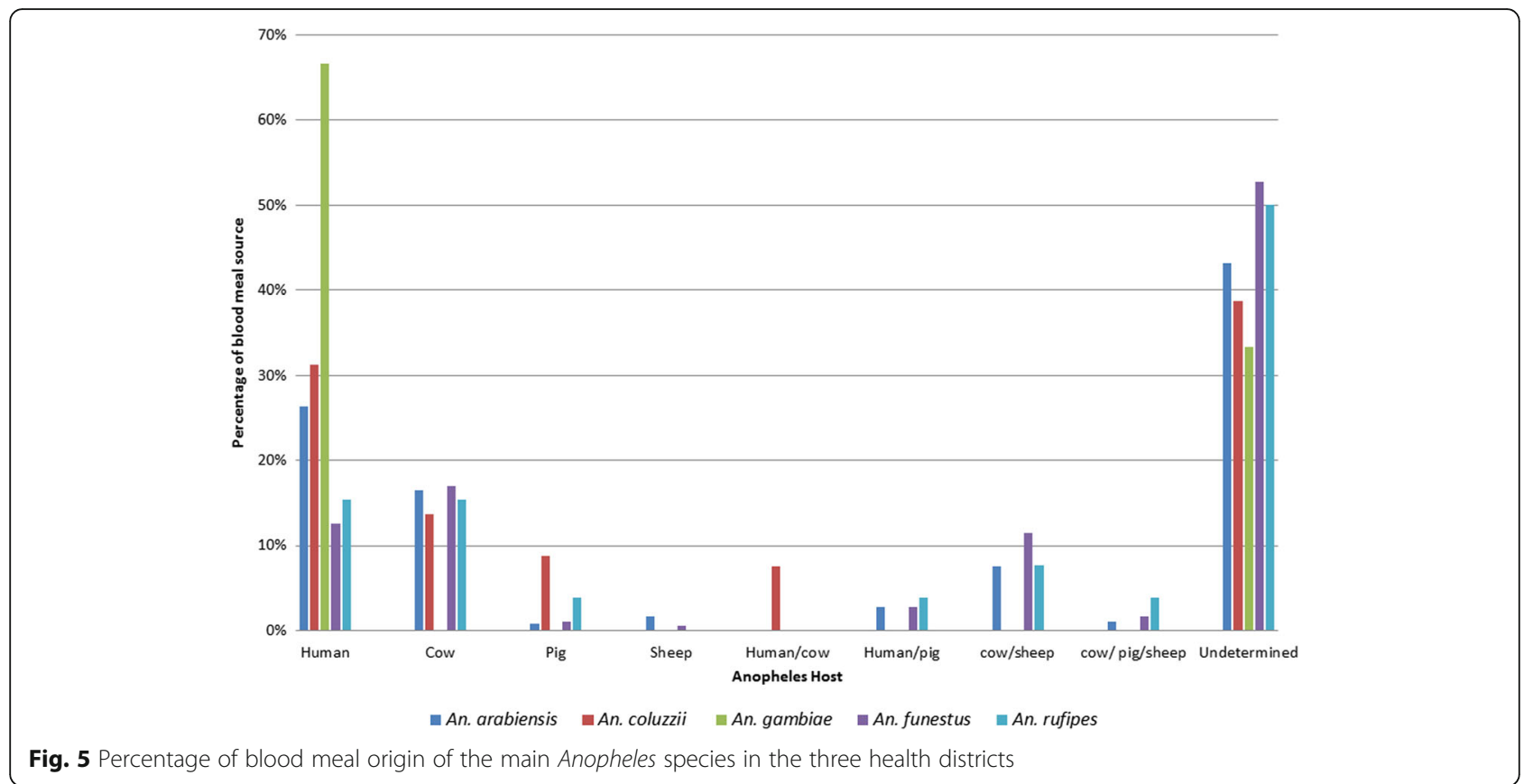

and Pitoa $\left(\chi^{2}=0.014, d f=3, P>0.05\right)$. However, An. gambiae contributed to transmission mainly in 2011 in Mayo Oulo with an EIR of $0.019 \mathrm{ib} / \mathrm{p} / \mathrm{n}$ and in 2013 in Garoua with an EIR of $0.01 \mathrm{ib} / \mathrm{p} / \mathrm{n}$ (Table 5).

\section{Discussion}

The identification and incrimination of vectors in malaria transmission as well as their relative contribution to transmission is critical for the implementation of an efficient malaria control strategy. Some control programmes like the Garki project, failed because of the erroneous identification of the vectors involved in malaria transmission, and insecticide resistance in An. arabiensis in Nigeria [35, 36]. To date, malariologists have paid little or no attention in most areas to An. rufipes as this species has generally exhibited high zoophilic tendencies. Elsewhere, the abundance of this species was found to peak particularly at the end of the rainy season

Table 4 Summary of overall entomological data

\begin{tabular}{|c|c|c|c|c|c|c|c|c|c|c|c|c|c|c|c|c|c|}
\hline \multirow{2}{*}{$\begin{array}{l}\text { Health } \\
\text { district }\end{array}$} & \multirow{2}{*}{$\begin{array}{l}\text { Anopheline } \\
\text { species }\end{array}$} & \multicolumn{4}{|l|}{2011} & \multicolumn{4}{|l|}{2012} & \multicolumn{4}{|l|}{2013} & \multicolumn{4}{|l|}{2014} \\
\hline & & $\mathrm{CSP}+(n)$ & IR & ma & EIR & $\mathrm{CSP}+(n)$ & IR & ma & EIR & $\mathrm{CSP}+(n)$ & IR & ma & EIR & $\operatorname{CSP}+(n)$ & IR & ma & EIR \\
\hline \multirow[t]{5}{*}{ Garoua } & An. gambiae & $15(888)$ & 0.017 & 20.137 & 0.340 & $8(661)$ & 0.012 & 8.902 & 0.108 & $32(1,408)$ & 0.023 & 17.118 & 0.389 & $6(318)$ & 0.019 & 4.206 & 0.079 \\
\hline & An. funestus & $1(49)$ & 0.020 & 1.137 & 0.023 & $1(56)$ & 0.018 & 0.775 & 0.014 & $4(158)$ & 0.025 & 1.922 & 0.049 & $2(70)$ & 0.029 & 1.020 & 0.029 \\
\hline & An. pharoensis & $5(344)$ & 0.015 & 6.225 & 0.090 & $0(12)$ & 0 & 0.118 & 0 & $4(230)$ & 0.017 & 2.716 & 0.047 & $1(14)$ & 0.071 & 0.833 & 0.060 \\
\hline & An. rufipes & $1(21)$ & 0.048 & 0.657 & 0.031 & $1(39)$ & 0.026 & 0.657 & 0.017 & $1(43)$ & 0.023 & 0.441 & 0.010 & $0(0)$ & - & 0.539 & - \\
\hline & An. paludis & $0(0)$ & 0 & 0.029 & - & $2(51)$ & 0.039 & 1.186 & 0.047 & $3(88)$ & 0.034 & 1.118 & 0.038 & $0(7)$ & 0 & 0.324 & 0 \\
\hline \multirow[t]{5}{*}{ Pitoa } & An. gambiae & $39(1,133)$ & 0.034 & 39.736 & 1.368 & $26(1,045)$ & 0.025 & 24.264 & 0.604 & $14(396)$ & 0.035 & 22.111 & 0.782 & 11 (859) & 0.013 & 21.880 & 0.280 \\
\hline & An. funestus & $5(161)$ & 0.031 & 4.472 & 0.139 & $2(88)$ & 0.023 & 2.014 & 0.046 & $1(36)$ & 0.028 & 0.944 & 0.026 & $0(31)$ & 0 & 0.9 & 0 \\
\hline & An. pharoensis & 8 (169) & 0.047 & 4.222 & 0.200 & $0(31)$ & 0 & 0.653 & 0 & $2(54)$ & 0.037 & 2.875 & 0.106 & $0(10)$ & 0 & 2.05 & 0 \\
\hline & An. rufipes & $4(99)$ & 0.040 & 5.486 & 0.222 & $1(164)$ & 0.006 & 3.569 & 0.022 & $1(19)$ & 0.053 & 0.472 & 0.025 & $0(14)$ & 0 & 0.51 & 0 \\
\hline & An. paludis & $2(74)$ & 0.027 & 1.806 & 0.049 & $0(60)$ & 0 & 1.944 & 0 & $2(49)$ & 0.041 & 1.278 & 0.052 & $0(0)$ & - & 0.04 & - \\
\hline \multirow[t]{5}{*}{ Mayo Oulo } & An. gambiae & 19 (492) & 0.039 & 39.361 & 1.520 & $1(122)$ & 0.008 & 3.472 & 0.028 & $8(157)$ & 0.051 & 6.241 & 0.318 & $0(24)$ & 0 & 11.163 & 0 \\
\hline & An. funestus & $2(22)$ & 0.091 & 1.889 & 0.172 & $1(40)$ & 0.025 & 1.278 & 0.032 & $1(33)$ & 0.030 & 1.037 & 0.031 & $0(0)$ & - & 1 & - \\
\hline & An. pharoensis & $0(36)$ & 0 & 2.056 & - & $0(2)$ & 0 & 0.083 & 0 & $1(24)$ & 0.042 & 1.056 & 0.044 & $1(29)$ & 0.034 & 0.667 & 0.023 \\
\hline & An. rufipes & $2(35)$ & 0.057 & 8.417 & 0.481 & $4(155)$ & 0.026 & 11.083 & 0.286 & $2(49)$ & 0.041 & 7.852 & 0.320 & $0(0)$ & - & 10.833 & - \\
\hline & An. paludis & $0(0)$ & 0 & 0.028 & - & $0(3)$ & 0 & 0.111 & 0 & $0(13)$ & 0 & 0.481 & 0 & $0(0)$ & - & 0.333 & - \\
\hline
\end{tabular}

Abbreviations: CSP+ number of mosquitoes positive to CSP, CSP circumsporozoite protein, EIRentomological inoculation rate (infectious bites/person/night, IR infection rate, ma man biting rate (bites/person/night), $n$ number of mosquitoes examined by CSP ELISA 
Table 5 Implication of members of Anopheles gambiae complex in malaria transmission

\begin{tabular}{|c|c|c|c|c|c|c|c|c|c|c|c|c|c|c|c|c|c|}
\hline \multirow{2}{*}{$\begin{array}{l}\text { Health } \\
\text { district }\end{array}$} & \multirow{2}{*}{$\begin{array}{l}\text { Anopheline } \\
\text { species }\end{array}$} & \multicolumn{4}{|l|}{2011} & \multicolumn{4}{|l|}{2012} & \multicolumn{4}{|l|}{2013} & \multicolumn{4}{|l|}{2014} \\
\hline & & $\mathrm{CSP}+(n)$ & ma & $\mathbb{R}$ & EIR & $\mathrm{CSP}+(n)$ & ma & $\mathbb{R}$ & EIR & $\mathrm{CSP}+(n)$ & ma & IR & EIR & $\mathrm{CSP}+(n)$ & ma & $\mathbb{R}$ & EIR \\
\hline \multirow[t]{3}{*}{ Garoua } & An. arabiensis & $1(78)$ & 0.76 & 0.01 & 0.01 & $1(31)$ & 0.3 & 0.03 & 0.01 & $3(75)$ & 0.74 & 0.04 & 0.029 & $1(7)$ & 0.07 & 0.14 & 0.0098 \\
\hline & An. coluzzii & $1(49)$ & 0.48 & 0.02 & 0.01 & $0(23)$ & 0.23 & 0 & 0 & $1(42)$ & 0.41 & 0.02 & 0.01 & $0(18)$ & 0.18 & 0 & 0 \\
\hline & An. gambiae & $0(11)$ & 0.11 & 0 & 0 & $0(7)$ & 0.07 & 0 & 0 & $1(2)$ & 0.02 & 0.5 & 0.01 & $0(4)$ & 0.04 & 0 & 0 \\
\hline \multirow[t]{3}{*}{ Pitoa } & An. arabiensis & $2(113)$ & 1.57 & 0.02 & 0.028 & $1(67)$ & 0.93 & 0.01 & 0.014 & $1(86)$ & 1.19 & 0.01 & 0.014 & $1(71)$ & 0.7 & 0.01 & 0.0098 \\
\hline & An. coluzzii & $1(67)$ & 0.93 & 0.01 & 0.014 & $1(33)$ & 0.46 & 0.03 & 0.014 & $0(15)$ & 0.21 & 0 & 0 & $1(20)$ & 0.2 & 0.05 & 0.0098 \\
\hline & An. gambiae & $0(14)$ & 0.19 & 0 & 0 & $0(17)$ & 0.24 & 0 & 0 & $0(6)$ & 0.08 & 0 & 0 & $0(15)$ & 0.15 & 0 & 0 \\
\hline \multirow[t]{3}{*}{ Mayo Oulo } & An. arabiensis & $5(83)$ & 1.54 & 0.06 & 0.093 & $2(6)$ & 0.11 & 0.33 & 0.037 & $2(17)$ & 0.31 & 0.12 & 0.037 & $0(3)$ & 0.06 & 0 & 0 \\
\hline & An. coluzzii & $0(8)$ & 0.15 & 0 & 0 & $0(1)$ & 0.02 & 0 & 0 & $0(3)$ & 0.06 & 0 & 0 & $0(0)$ & 0 & - & - \\
\hline & An. gambiae & $1(5)$ & 0.09 & 0.2 & 0.019 & $0(1)$ & 0.02 & 0 & 0 & $0(2)$ & 0.04 & 0 & 0 & $0(2)$ & 0.04 & 0 & 0 \\
\hline
\end{tabular}

Abbreviations: CSP+ number of mosquitoes positive to CSP, CSP circumsporozoite protein, EIR entomological inoculation rate (infectious bites/person/night, IR infection rate, $m a$ man biting rate (bites/person/night), $n$ number of mosquitoes examined by CSP ELISA

in rice-growing areas, with very short periods of malaria outbreak resulting [17-20]. Anopheles rufipes breed commonly in small collections of water such as residual puddles in river beds, hoof prints of cattle, swamps and rice irrigation schemes, with the larvae staying close to the borders and among vegetation. This is important as cattle rearing and rice cultivation and irrigation are common practices in the study sites, which usually experience floods with long retention of surface water during the wet season. As part of a study to determine the impact of insecticide resistance on the effectiveness of vector control tools like the LLIN in the north of Cameroon, the observed unexpectedly high density and anthropophilic behaviour of this species incited our curiosity to investigate its role in P. falciparum transmission. For the first time in Cameroon, An. rufipes has been identified as an important local vector of $P$. falciparum. A few earlier studies have described this species as weakly anthropophilic [18] and potentially involved in malaria transmission [3, 37, 38]. More recently in Burkina Faso, Plasmodium was detected in An. rufipes oocyts, further implicating it as a potential vector of human malaria parasites [39]. Thus, An. rufipes may be a more important and wider spread vector than previously thought and therefore this is important for malaria elimination strategies.

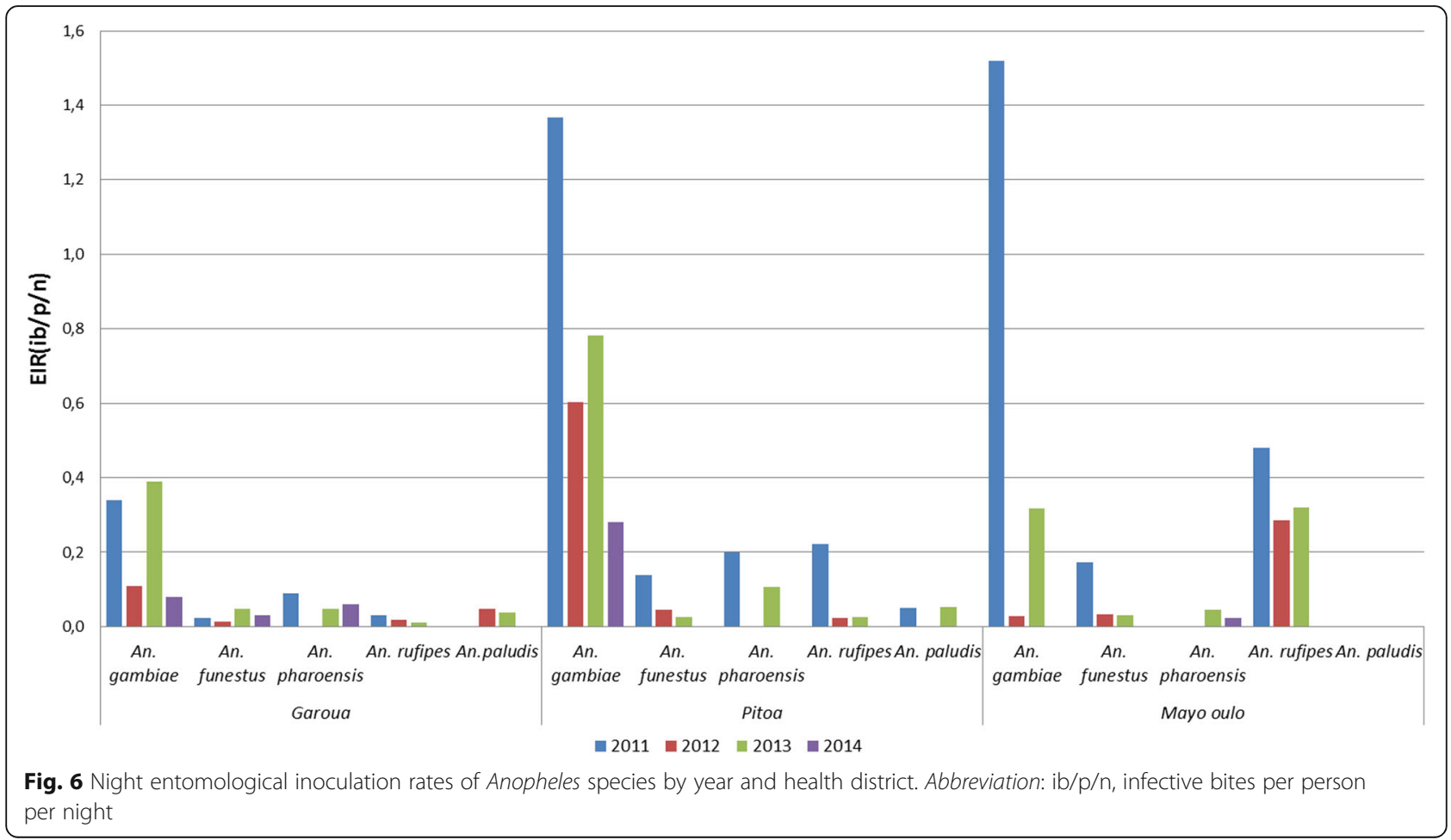


In Cameroon, five major malaria vectors (An. gambiae, An. funestus, An. arabiensis, An. nili and An. moucheti) have been described [10] with nine secondary vectors of local importance (An. paludis, An. carnevalei, An. coustani, An. marshallii, An. ziemanni, An. pharoensis, An. hancocki, An. wellcomei and An. ovengensis). Anopheles rufipes is now added to this plethora of vectors, further complicating the malaria vectorial system in the country. In the past, the role of this species in malaria transmission was largely neglected due its strong zoophilic tendency which leads to claims of its lack of importance. Moreover, An. rufipes had high parous rate wherever it was collected, suggesting the propensity to survive longer and being able to maintain and even extend $P$. falciparum transmission beyond the normal duration.

The vast plethora of Anopheles species observed in this study could be linked to the diversity of existing biotopes that enhance the proliferation of such species within the health districts. Anopheles arabiensis, An. coluzzii and An. gambiae (s.s.) were the An. gambiae (s.l.) siblings found with An. arabiensis being the most frequently encountered species. The relative abundance of An. gambiae (s.s.) and An. arabiensis varied across the years and by health districts with twice as many $A n$. arabiensis. This is unlike observations by Robert et al. [40] in southern Burkina where the density of An. gambiae (s.s.) was nine-fold greater than that of An. arabiensis among residual endophilic mosquitoes. This difference however, might be due to differences in the microenvironments and the methods of collection. Both species are typical malaria vectors of the sahelian zone [41], with their densities peaking especially during the rainy season. As observed with An. rufipes in this study, species like An. pharoensis, An. funestus and An. coustani have been shown to contribute significantly to malaria transmission [23]. For An. funestus, the density remained relatively constant irrespective of the season [42]. Akin to studies conducted in Burkina Faso, An. rufipes constituted a significant proportion of the anophelines collected in this study [39]. This however differs markedly with observations from the HLC collections in the coastal areas and northern regions of Cameroon [21, 22] and Chad [43], where An. rufipes density was low. The vast number of prolific breeding sites (rice fields, river banks and pools) during the study periods may explain the high density of An. rufipes [19,20].

With regard to the biting rates of the anophelines, except in Mayo Oulo where the highest An. rufipes densities were recorded in 2012 and 2013, An. gambiae (s.l.) generally had the highest biting rates throughout the study (Table 2). Analyses of the blood meal sources among the members of the An. gambiae complex revealed An. gambiae despite its low density compared to An. coluzzii and An. arabiensis, to be the most anthropophagic. Amongst the vectors for which the blood meal source was confirmed, they were observed to feed mainly on cow, which is the most widely domesticated animal in this part of the country. Anopheles rufipes was observed to feed on both humans and animals confirming the species opportunistic behaviour or may be simply due to the imposing environmental conditions. Livestock rearing is a common practice with animals like dog, chicken, horse, goat and donkey in addition to those analyzed. Unlike previous reports on $A n$. funestus being the most anthropophagic Anopheles species $[33,44-47]$ its human blood index in this study was very low. This may be due to the presence of a variety of domestic animals that provide an alternative source for blood-feeding or due to the occurrence of other members of the An. funestus group of species. In fact, Anopheles funestus (s.l.) comprises at least nine species that are morphologically identical [3]: An. funestus (s.s.), An. vaneedeni Gillies \& Coetzee, An. parensis Gillies, An. aruni Sobti, $A n$. confusus Evans \& Leeson, An. rivulorum Leeson, $A n$. fuscivenosus Leeson, An. leesoni Evans and An. brucei Service. All except An. funestus (s.s.) and to some extent An. rivulorum are purported to be exclusively zoophilic and non-vectors [48]. Despite the fact that many authors reported a high infection rate of An. funestus during dry season [3, 49], Antonio-Nkondjio et al. [22] observed a pronounced anthropohilic behaviour of An. funestus during the wet season while this species was exclusively zoophilic during the dry season. Other earlier studies $[50,51]$ also reported besides An. funestus (s.s.) the presence of Anopheles leesoni Evans and Anopheles rivulorum-like in tributaries of the Benoue River in the northern region of Cameroon. Based on these observations and the current HBI results, there is the likelihood of the existence of some zoophilic members of An. funestus group in this area. Therefore, it would be important that subsequent studies in this area should consider the identification of the members of the An. funestus group of species and their contribution to human malaria transmission.

On a general note, in addition to the Anopheles species displaying endophagic and exophagic tendencies, the parity rates were observably high in all HDs. Thus, despite the high LLIN coverage in the study localities [52], the malaria vectors survive long enough to sustain malaria transmission locally.

The infection rates varied enormously between the health districts. Overall, seven Anopheles species (An. arabiensis, An. coluzzii, An. gambiae, An. funestus, An. pharoensis, An. rufipes and $A n$. paludis) were found infected with $P$. falciparum. Even though the CSP rates were higher than those obtained elsewhere under similar eco-epidemiological conditions [22], measures were taken to minimize false positive CS ELISA in these areas with an extensive animal reservoir flow for blood-feeding. Thus, only high absorbance readings (mean plus three standard deviations of negative 
controls) were considered. Nevertheless, this CSP-ELISA may overestimate the infection rate and all positive samples need to be confirmed with PCR [53]. Relatively low malaria transmission intensity was observed throughout the years in all health districts. The observed EIR estimate of 0.014 to 1.221 infective bites/person/night was consistent with other records in the sahelian zone [25]. However, the transmission intensity during the study was pronounced in the irrigated rice paddies of Pitoa, which is not uncommon to other such irrigation schemes that generate a variety of entomological and epidemiological situations with permanent water bodies that are prolific for Anopheles breeding and consequently increasing the risk of malaria in surrounding population [54].

\section{Conclusions}

The study highlights the epidemiological role of $A n$. rufipes alongside the members of the Anopheles gambiae complex, and several other sympatric species in human malaria transmission during the wet season in northern Cameroon. Thus, for the first time in Cameroon, the role of An. rufipes as an important local malaria vector has been made evident. The study also portrays the need to carry out further studies to document the implication of this species and other presumably non-malaria vectors in human malaria transmission in other parts and to review and update the malaria entomological profile in the country and the Afrotropical region.

\section{Abbreviations \\ CSP: Circumsporozoite protein; EIR: Entomological inoculation rates; ELISA: Enzyme-linked-immunosorbent assay; HD: Health district; HLC: Human landing catch; LLINs: Long-lasting insecticide-treated nets; PSC: Pyrethrum spray collection}

\section{Acknowledgements}

This work received financial assistance from the Bill and Melinda Gates Foundation (Grant Number: 48499101) and World Health Organization. We acknowledge the technical support of the NMCP, OCEAC and the Biotechnology Center of University of Yaoundé I. We are indebted to the authorities of the Garoua, Pitoa and Mayo Oulo Health Districts, the population and participants in the 38 villages for their collaboration. The authors are grateful to the three anonymous reviewers for their helpful comments that greatly improved the former versions of this manuscript.

\section{Funding}

The Bill and Melinda Gates Foundation (Grant Number: 48499101) and World Health Organization.

\section{Availability of data and material}

The datasets generated and/or analyzed during the current study are available at the National Reference Unit for vector control, Biotechnology Center University of Yaounde I and available from the corresponding author on reasonable request. The dataset supporting the conclusions of this article is included within the article.

\section{Authors' contributions}

$E F, J B, P A, T B K, A P M$ and MJD conceived and planned the study and its design. RNT, JB, PA, JE JCT, SP and JA monitored the field and laboratory studies, analyzed and interpreted the data. TNR, JB and PA drafted the manuscript. RL, CA, EF and AT reviewed and helped write the manuscript. All authors made intellectual input to the study. All authors read and approved the final manuscript.

\section{Competing interests}

The authors declare that they have no competing interests.

\section{Consent for publication}

Not applicable.

\section{Ethics approval and consent to participate}

Ethical clearance was obtained from the National Ethics Committee of Cameroon (FWA IRB00001954, and authorization number 102/CNE/SE/09). Consent of household heads was sought prior to using the house for mosquito collection. Participation in mosquito collection was strictly voluntary, following written informed consent, and only those adequately trained on the collection process were retained. Collectors were provided with anti-malaria drugs to take in case of malaria.

\section{Author details}

${ }^{1}$ Faculty of Science, Department of Biochemistry, University of Yaounde I, P.O. Box 813- Messa, Yaounde, Cameroon. ${ }^{2}$ National Reference Unit for Vector Control, The Biotechnology Center, University of Yaoundé I, P.O. Box 3851-Messa, Yaoundé, Cameroon. ${ }^{3}$ Ministry of Public Health, National Malaria Control Programme, P.O. Box 14386, Yaoundé, Cameroon. ${ }^{4}$ Laboratoire de Recherche sur le Paludisme, Organisation de Coordination pour la lutte Contre les Endémies en Afrique Centrale (OCEAC), P.O. Box 288, Yaoundé, Cameroon. ${ }^{5}$ Global Malaria Programme, World Health Organization, Avenue Appia 20, Geneva, Switzerland. ${ }^{6}$ WHO country Office in Cameroon, PO BOX 155, Yaounde, Cameroon. ${ }^{7}$ Malaria Programme, Wellcome Trust Sanger Institute, Hinxton, Cambridge, UK. ${ }^{8}$ Department of Vector Biology, Liverpool School of Tropical Medicine, Pembroke Place, Liverpool L3 5QA, UK.

Received: 10 October 2016 Accepted: 8 December 2016

Published online: 11 January 2017

\section{References}

1. Harbach RE, Kitching IJ. Phylogeny and classification of the Culicidae (Diptera). Syst Entomol. 1998;23:327-70.

2. Harbach RE. Genus Anopheles Meigen, 1818. 2013. http://mosquitotaxonomic-inventory.info/genus-emanophelesem-meigen-1818-0. Accessed 19 Aug 2016.

3. Gillies M, DeMeillon B. The Anophelinae of Africa South of the Sahara (Ethiopian Zoogeographical Region. Johannesburg: South African Medical Research Institute; 1968. no.54.

4. Gillies MT, Coetzee M. A supplement to the Anophelinae of Africa South of the Sahara (Afrotropical Region). Johannesburg: South Africa Institute for Medical Research; 1987.

5. Hervy JF, Le Goff G, Geoffroy B, Herve JP, Manga L, Brunhes J. Les Anophèles de la région afrotropicale. Paris: France; 1998.

6. White GB. Anopheles gambiae complex and disease transmission in Africa. Trans R Soc Trop Med Hyg. 1974;68:278-98.

7. Sharp BL, Sueur DL. Behavioural variation of Anopheles arabiensis (Diptera: Culicidae) populations in Natal, South Africa. Bull Entomol Res. 1991;81:107-10.

8. Vitousek PM, Mooney HA, Lubchenco J, Melillo JM. Human domination of Earth's ecosystems. Science. 1997;277:494-9.

9. Derraik JG, Slaney D. Anthropogenic environmental change, mosquitoborne diseases and human health in New Zealand. Ecohealth. 2007;4:72-81.

10. Antonio-Nkondjio C, Kerah CH, Simard F, Awono-Ambene P, Chouaibou M, Tchuinkam T, et al. Complexity of the malaria vectorial system in Cameroon: contribution of secondary vectors to malaria transmission. J Med Entomol. 2006;43:1215-21.

11. Awono-Ambene HP, Kengne P, Simard F, Antonio-Nkondjio C, Fontenille D. Description and bionomics of Anopheles (Cellia) ovengensis (Diptera: Culicidae), a new malaria vector species of the Anopheles nili group from south Cameroon. J Med Entomol. 2004;41:561-8.

12. Tabue RN, Nem T, Atangana J, Bigoga JD, Patchoke S, Tchouine F, et al. Anopheles ziemanni a locally important malaria vector in Ndop health district, north west region of Cameroon. Parasit Vectors. 2014;7:262.

13. Fontenille D, Wandji S, Djouaka R, Awono-Ambene HP. Anopheles hancocki, vecteur secondaire du paludisme au Cameroun. Bull Lia Doc OCEAC. 2000; 33:23-6.

14. Fondjo E. Etude du comportement du complexe Anopheles gambiae et de la transmission du paludisme dans deux faciès éco-climatique au Mali et au Cameroun. Université de Bamako: Thèse de 3ème Cycle; 1996. 
15. Mukiama TK, Mwangi RW. Seasonal population changes and malaria transmission potential of Anopheles pharoensis and the minor anophelines in Mwea irrigation Scheme, Kenya. Acta Trop. 1989;46:181-9.

16. Wanji S, Tanke T, Atanga NS, Ajonina C, Tendongfor N, Fontenille D. Anopheles species of the mount Cameroon region: biting habits, feeding behaviour ant entomological inoculation rates. Trop Med Int Health. 2003;8:643-9.

17. Hamon J. Les moustiques anthropophiles de la région de Bobo-Dioulasso (République de Haute-Volta): cycles d'agressivité et variations saisonnières. Ann Soc Ent Fr. 1963;132:85-114.

18. Bruce-Chwatt J, Gockel C, Weitz B. A study of the blood-feeding patterns of Anopheles mosquitos through precipitin tests. Results of collaborative work for the period 1955-59 and their application to malaria eradication programmes. Bull World Health Organ. 1960;22:685-720.

19. Githeko AK, Service MW, Mbogo CM, Atieli FK, Juma FO. Origin of blood meals in indoor and outdoor resting malaria vectors in western Kenya. Acta Trop. 1994;58:307-16.

20. Dolo G, Briet OJT, Dao A, Traore SF, Bouare M, Sogoba N, et al. Malaria transmission in relation to rice cultivation in the irrigated Sahel of Mali. Acta Trop. 2004;89:147-59.

21. Bigoga JD, Manga L, Titanji VPK, Coetzee M, Leke RGF. Malaria vectors and transmission dynamics in the coastal south-western Cameroon. Malar J. 2007;6:5.

22. Antonio-Nkondjio C, Atangana J, Ndo C, Awono-Ambene P, Fondjo E, Fontenille D, et al. Malaria transmission and rice cultivation in Lagdo, northern Cameroon. Trans R Soc Trop Med Hyg. 2008;102:352-9.

23. Robert V, Dieng H, Lochouran L, Traore SF, Trape JF, Simondon F, et al. Malaria transmission in the rural zone of Niakhar, Senegal. Trop Med Int Health. 1998:3:667-77.

24. Robert V, Broek A, Stevens P, Slootweg R, Petrarca V, Coluzzi M, et al. Mosquitoes and malaria transmission in irrigated rice-fields in the Benoue valley of northern Cameroon. Acta Trop. 1992;52:201-4

25. Atangana J, Bigoga JD, Patchoke S, Ndjemai MN, Tabue RN, Nem TE, et al. Anopheline fauna and malaria transmission in four ecologically distinct zones in Cameroon. Acta Trop. 2010;115:131-6.

26. Detinova TS. Age grouping methods in Diptera of medical importance, with special reference to some vectors of malaria. Monogr Ser World Health Organ. 1962:47:13-191.

27. Service MW. A critical review of procedures for sampling populations of adult mosquitoes. Bull Entomol Res. 1977;67:343-82.

28. Collins FH, Mendez MA, Rasmussen MO, Mehaffey PC, Besansky NJ, Finnerty $\checkmark$. A ribosomal RNA gene probe differentiates member species of the Anopheles gambiae complex. Am J Trop Med Hyg. 1987;37:37-41.

29. Favia GA, Della T, Bagayoko M, Lanfrancotti A, Sagnon NF, Touré YT, et al. Molecular identification of sympatric chromosomal forms of Anopheles gambiae and further evidence of their reproductive isolation. Insect Mol Biol. 1997;6:377-83.

30. Burkot TR, Williams JL, Schneider I. Identification of Plasmodium falciparuminfected mosquitoes by a double antibody enzyme linked immunosorbent assay. Am J Trop Med Hyg. 1984;33:783-8.

31. Wirtz RA, Zavala F, Charoenvit Y, Campbell GH, Burkot TR, Schneider I, et al. Comparative testing of Plasmodium falciparum sporozoite monoclonal antibodies for ELISA development. Bull Wld Health Organ. 1987;65:39-45.

32. Somboon P, Morakote N, Kootathep S, Trsanarom U. Detection of sporozoites of Plasmodium vivax and Plasmodium falciparum in mosquitoes by ELISA: false positivity associated with bovine and swine blood. Trans $R$ Soc Trop Med Hyg. 1993;87:322-32.

33. Beier JC, Perkins PV, Wirtz RA, Koros J, Diggs D, Gargam-li TP, et al. Bloodmeal identification by direct enzyme-linked immunosorbent assay (ELISA) tested on Anopheles (Diptera: Culicidae) in Kenya. J Med Entomol. 1988;25:9-16

34. Lardeux F, Loayza P, Bouchite B, Chavez T. Host choice and human blood index of Anopheles pseudopunctipennis in a village of the Andean valleys of Bolivia. Malar J. 2007;6:8-10

35. Molineaux L, Gramiccia G, The Garki Project. Research on the epidemiology and control of malaria in the Sudan Savanna of West Africa. Geneva: World Health Organization; 1980.

36. Green CA. Malaria epidemiology and anopheline cytogenetics. In: Pal R, Kitzmiller JB, Kanda T, editors. Cytogenetics and genetics of vectors. Amsterdam: Elsevier Biomedical Press; 1981.

37. Holstein M. Un nouveau vecteur du paludisme en AOF: Anopheles rufipes Gough 1910. Off. Rech. Sci. D'Outre-Mer. 1949; № 379.
38. Gillies M. The role of secondary vectors of malaria in north-east Tanganyika. Trans R Soc Trop Med Hyg. 1964;58:154-8.

39. Da D, Mouline K, Awono-Ambene H. Anopheles rufipes remains a potential malaria vector after the first detection of infected specimens in 1960 in Burkina Faso. J Infect Dis Ther. 2013;1:112.

40. Robert V, Carnevale P, Ouédraogo V, Petrarca V, Coluzzi M. La transmission du paludisme humain dans un village de savane du sud-ouest du Burkina Faso. Ann Soc Belge Med Trop. 1988;68:107-21.

41. Labbo R, Fouta A, Jeanne I, Ousmane I, Duchemin J. Anopheles funestus in Sahel: new evidence from Niger. Lancet. 2004;363:660-10.

42. Adam J, Hamon J, Bailly-Choumara H. Observations sur la biologie et le pouvoir vecteur d'une population d'Anopheles gambiae résistante a la dieldrine en Haute-Volta. Bull Soc Path Exot. 1960;53:1043-53.

43. Kerah-Hinzoumbe C, Peka M, Antonio-Nkondjio C, Donan-Gouni I, AwonoAmbene P, Same-Ekobo A, et al. Malaria vectors and transmission dynamics in Goulmoun, a rural city in south-western Chad. BMC Infect Dis. 2009;9:71-82.

44. Antonio-Nkondjio C, Awono-Ambene H, Toto J, Meunier J, Zebaze-Kemleu S, Nyambam R, et al. High malaria transmission intensity in sub-urban area of Yaoundé: the capital city of Cameroon. J Med Entomol. 2002;39:350-5.

45. Githeko AK, Adungo NI, Karanja DM, Hawley WA, Vulule JM, Seroney IK. Some observations on the biting behaviour of Anopheles gambiae s.S., Anopheles arabiensis, and Anopheles funestus and their implications for malaria control. Exp Parasitol. 1996;82:306-15.

46. Mbogo CN, Kabiru EW, Muiruri SK, Nzovu JM, Ouma JH, Githure Jl, et al. Blood feeding behavior of Anopheles gambiae s.l. and Anopheles funestus in Kilifi District, Kenya. J Am Mosq Control Assoc. 1993:9:225-7.

47. Jjumba J, Mosha F, Lindsay SW. Malaria transmission risk variations derived from different agricultural practices in an irrigated area of northern Tanzania. Med Vet Entomol. 2002;16:28-38.

48. Wilkes TJ, Matola YG, Charlwood JD. Anopheles rivulorum, a vector of human malaria in Africa. Med Vet Entomol. 1996;10:108

49. Cohuet A, Simard F, Wondji CS, Antonio-Nkondjio C, Awono-Ambene P, Fontenille D. High malaria transmission intensity due to Anopheles funestus (Diptera: Culicidae) in a village of savannah-forest transition area in Cameroon. J Med Entomol. 2004;41:901-5.

50. Cohuet A, Simard F, Toto JC, Kengne P, Coetzee M, Fontenille D. Species identification within the Anopheles funestus group of malaria vectors in Cameroon and evidence for a new species. Am J Trop Med Hyg. 2003;69:200-5.

51. Mouchet J, Gariou J. Répartition géographique et écologique des anophèles au Cameroun. Bull Soc Path Exot. 1961;54(1):102-18.

52. INS/Cameroun. Rapport MILDA 12092013 - MILDA-Rapport [Internet]. Available from: http://www.statistics-cameroon.org/downloads/MILDA/ MILDA-Rapport-complet.pdf. Accessed 11 Dec 2016.

53. Durnez $L$, Van Bortel W, Denis $L$, Roelants $P$, Veracx A, Trung HD, et al. False positive circumsporozoite protein ELISA: a challenge for the estimation of the entomological inoculation rate of malaria and for vector incrimination. Malar J. 2011;10:195

54. Carnevale P, Guillet P, Robert V, Fontenille D, Doannio J, Coosemans M, et al. Diversity of malaria in rice growing areas of the Afrotropical region. Parassitologia. 1999:41:273-6.

\section{Submit your next manuscript to BioMed Central and we will help you at every step:}

- We accept pre-submission inquiries

- Our selector tool helps you to find the most relevant journal

- We provide round the clock customer support

- Convenient online submission

- Thorough peer review

- Inclusion in PubMed and all major indexing services

- Maximum visibility for your research

Submit your manuscript at www.biomedcentral.com/submit
) Biomed Central 